\title{
Sound Corporate Governance and Its Benefits in Financial Institutions: Does It Really Matter for Organizational Development
}

\author{
Md. Joynal Abedin' ${ }^{1}$, Syed Arif ${ }^{2}$ \\ ${ }^{1}$ Department of Finance, Faculty of Business Administration, American International University-Bangladesh, Dhaka, Bangladesh \\ ${ }^{2}$ Department of Economics, American International University-Bangladesh, Dhaka, Bangladesh
}

Email address:

mja.aiub@yahoo.com (Md. J. Abedin)

\section{To cite this article:}

Md. Joynal Abedin, Syed Arif. Sound Corporate Governance and Its Benefits in Financial Institutions: Does It Really Matter for Organizational Development. International Journal of Economics, Finance and Management Sciences.

Vol. 3, No. 5, 2015, pp. 507-525. doi: 10.11648/j.ijefm.20150305.22

\begin{abstract}
Corporate governance in modern times is a rising hot-cake concept that is being introduced worldwide almost in all corporations. The primary purpose of corporate governance is to ensure transparency and equality between a corporation and its shareholders. The intention of this paper is to assess the overall concept of corporate governance, and its practices present in financial institutions. Corporate governance right now is a rising concern all-inclusive, and its streak is beginning to be seen nowadays in our country as well. In our study, we have interviewed executive personnel from financial institutions to find out how much of corporate governance practices are followed in the corporate financial sector. Subsequently, we have tried to identify the benefits of it in financial institutions and the correlation with organizational development.
\end{abstract}

Keywords: Corporate Governance, Financial Institutions, Organizational Development, Benefits of Financial Institutions

\section{Introduction}

Corporate governance is best described as a set of mechanisms and procedures through which corporations establish a foundation of principles to operate upon. Sir Adrian Cadbury in 'Global Corporate Governance Forum' defined corporate governance as a tool that creates and farms the equilibrium between economic and social goals and between individual and communal goals. Through the framework of corporate governance, it is possible to engage the efficient use of resources that equally requires accountability for the stewardship of those resources. The main purpose of corporate governance is to align as nearly as possible the interests of individuals, corporations, and society (Cadbury, 2000). In a broader sense, corporate governance discusses the devices, processes and relations by which corporations are controlled and directed (Shailer, Greg 2004). Governance mechanisms may include monitoring and evaluating the actions, policies and decisions of corporations and their agents. According to OECD, the corporate governance structures help to identify the distribution of rights and responsibilities between different participants (such as the board of shareholders, managers, directors, and other stakeholders in the corporation) and comprise the rules, regulations and procedures for assembling decisions in corporate dealings (OECD, 2004). Tricker and Adrian stated that corporate governance also includes the procedures and techniques through which corporations set their objectives and pursue them in a context of the social, regulatory and market environment (Tricker, Adrian, 2009).

A vital notion and effort by corporate governance is to ensure accountability and responsibility through a set of principles, which should be fused into every part of the organization. The ultimate emphasis of corporate governance is to confirm better and effective protection for all stakeholders by holding the firm's directors and managers accountable. As a concept, corporate governance is viewed as a recent issue, but there is, in fact, nothing new about the theory. Corporate governance has existed along the origin of the corporation itself as long as there has been a significant trade, creating the need for responsibility in the handling of money and the conduct of commercial activities. Through transparency and accountability, corporate governance brings professionalism in the management system of a corporate body and enriches the credibility and acceptability of all 
stakeholders. Basel Committee, 1997 states that a good corporate governance model and practice involves appropriate and effective fundamentals of legal, regulatory and institutional basis. But the integrity and overall performance of the corporate governance model can be disturbed by a variety of factors including the system of business laws and accounting standards. Supervisors are therefore fortified to be conscious of legal and institutional inhibitions towards solid corporate governance, and to take steps to protect effective foundations for corporate governance where it is within their legal authority to do so (Basel Committee, 1997).

The concept, model, and the theory of corporate governance in developing economies is important for several reasons. Unfortunately, corporate governance practices in Bangladesh are quite vague in most companies and organizations. In fact, Bangladesh has lost the race to its neighbors and the global economy in corporate governance (Gillibrand, 2004). One probable reason for this absence of corporate governance is that most companies are family oriented. Companies feel reluctant to disclose information and expand governance practices. There is neither any value judgment nor any motivation and positive consequences for corporate governance practices in our country.

The current system in Bangladesh does not offer any form of adequate legal, institutional and economic motivation for stakeholders to encourage and enforce corporate governance practices; hence failure in most of the ingredients of corporate governance is witnessed in Bangladesh. Fragile bankruptcy laws, no release of information regarding related party transactions, feeble regulatory system, poor general meeting scenario, inadequate number of active shareholder participations are some of the barricades to corporate governance which Mamtaz Uddin Ahmed and Mohammad Abu Yusuf have argued in their research "Corporate Governance: Bangladesh Perspective" (Mamtaz and Yusuf, 2005). However, the urgency of corporate governance in Bangladesh is growing. According to Khan, Securities and Exchange Commission of Bangladesh issued a statement on corporate governance Guidelines for the publicly listed companies of Bangladesh under Section 2CC of the Securities and Exchange Ordinance, 1969. The corporate governance Guidelines were issued on a provisional 'comply or explain' foundation, allowing some 'breathing space' for the companies to implement on the basis of their capabilities. Corporate governance practices in Bangladesh are progressively being familiarized in most companies and organizations. Among the companies, 66.7 percent of them have adopted corporate governance and 43.3 percent have agreement policy with national or international yardsticks though the fact remains that a considerable percentage of the top management does not fully understand or is willing to grasp the concept of corporate governance (Khan, 2007).

Corporate governance norms play a crucial role in the banking industry in Bangladesh. The fact that banks deal with public money makes public confidence of utmost importance for the development of banking industry in
Bangladesh. However, Huq and Bhuyian argues that it is uncertain that the practice of corporate governance in banking industry in Bangladesh is effective enough, because, a number of problems is reported to exist in corporate governance practices such as board members consisting of only family members, and inadequate bankruptcy laws (Huq and Bhuiyan, 2012).

\section{Objective of the Study}

The main objective of the study is to identify and analyze the benefits and negative aspects of corporate governance practices and how corporate governance models can help companies and organizations in Bangladesh. We also wish to detect the problems and loopholes that exist in corporate governance practices so that these problems can be examined and solutions can be constructed to overcome such problems, thereby highlighting the prospects of corporate governance practices.

In specific, the purpose of our study is to know the following:

- The current status of corporate governance practices in terms of accountability and transparency to stakeholders

- To what extent of fairness the practices of corporate governance actually is

- If corporate governance system in Bangladesh is transparent for all stakeholders in the financial institutions sector

\section{Review of Related Literature}

The core definition of corporate governance itself varies amongst authors. Sir Adrian Cadbury describes corporate governance as a "system" by which companies are directed and managed (Cadbury and Greenbury report, CFACG 1992). Another school of thought labels corporate governance as "structures and processes for decision making, accountability, control and behavior at the governing body" (Public accounts and Estimates Committee, 2002). And to others, corporate governance is about "finding alternatives" to ensure effective decision making in the corporate scenario (Pound 1995). According to The World Bank the framework of corporate governance should be based on four "pillars", of Responsibility, Accountability, Fairness and Transparency (RAFT).

In the case of corporate governance in the banking sector, three elements of literature stand out. Prowse, Furfine,

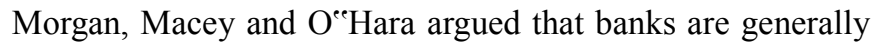
more opaque than non-financial firms. Although information asymmetries plague all sectors, evidence suggests that these informational asymmetries are larger with banks. From the perspective of banking, loan quality is not readily observable and can be hidden for long periods (Prowse, 1997; Furfine, 2001; Morgan, 2002; Macey and O'Hara, 2003).

The second aspect of literature describes how better corporate governance practices in banks can help their 
financial development and growth. Bushman and Smith presented in their study a framework that separates three channels through which financial accounting information can affect the investments, productivity, and value-added of firms, namely the use of financial accounting information by managers and investors, the use of financial accounting information in corporate control mechanisms and the use of financial accounting information to reduce information asymmetries among investors (Bushman and Smith, 2003). In the third strand, Jensen and Meckling views corporate governance practices in banks from the perspective of its impact on performance and efficiency of the banks themselves (Jensen and Meckling, 1976).

From the perspective of Bangladesh and the presence of corporate governance practices present in our country, Rashid et al have acknowledged six specific corporate governance characteristics in relation to current corporate governance practices in Bangladesh, namely legal and regulatory framework, weak institutional control, pre-dominant of individual investors, limited transparency and weak disclosure practices etc. and have examined board composition and firm performance from Bangladesh perspective. The study has also examined the influence of corporate board composition in the form of representation of outside independent directors on firms' economic performance in Bangladesh. The finding of the study has provided an insight to the regulators in this quest for harmonization of internal corporate governance practices (Rashid, A et al 2007). Also, Kutubi has examined board of director's size, independence and performance in an analysis of private commercial banks in Bangladesh. His work highlighted how much impact the board size and the independent directors can have on the performance of the local private commercial banks in Bangladesh. Statistical evidence shows significance positive relationship existed between the proportions of the independent directors and the performance of the banks (Kutubi, 2011).

\section{Methodology}

\subsection{Data Source}

At first, several research journals and articles from the internet, and other secondary sources of literature were consulted to gain an overall broad perspective about the corporate governance scenario in the present business world. To further broaden our knowledge, we had discussions with academics and researchers as well.

This necessary primary data were collected from three financial institutions using the questionnaire method as an extensive one. All the questions were kept as close-ended. Some secondary data about the institutions were collected from their annual reports.

\subsection{Research Design}

We designed our study targeting three financial institutions in Dhaka: The City Bank, Eastern Bank Limited, and Delta
Brac Housing Limited. As mentioned earlier, initially we had to go through several literature and information about corporate governance to get a clear understanding of the concept as a whole. Then we prepared a questionnaire to gain further understanding of the present corporate governance practices in our country. After having the required primary data, we proceeded to the analysis chapter where we had to study and examine the information gathered, and figure out the magnitude of the corporate governance tools present. After the analysis part, we went for the write up of the whole report and presented our findings through our study.

\subsection{Limitation of the Study}

For the preparation of this paper, we had to undergo the following limitations:

- Corporate Governance itself is a huge, complex issue to describe

- Because of tight malpractice rules and actions taken by the government, the institutions were extremely reluctant to disclose information

- For time and other resources limitation, we were able to interview only three financial institutions.

- The secondary data sources regarding corporation governance in our country were also few in numbers as there is a considerable lack of studies conducted on the corporate governance landscape in Bangladesh.

\section{Conceptual Framework and Definition}

\subsection{Conceptual Framework}

In the conceptual framework of corporate governance stewardship theory comes first; it suggests that the hierarchy level of a corporation prefer more meditation on extensive demand rather than personal desires (Schoorman \& Donaldson, 1997).

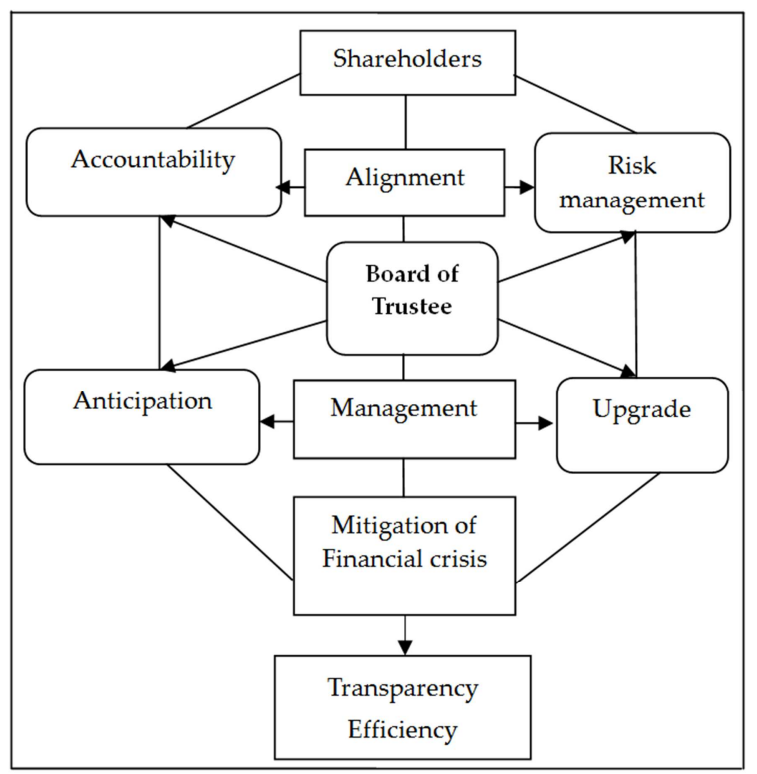

Figure 1. Conceptual Framework for Corporate Governance. 
According the main theme it is clear that the corporate governance actually maintains a broad chain within the corporation. In any organization the board of trustee is the basement of all activities. They can directly give the order to the employees or indirectly command through the management to achieve the mission and vision of the entity. It makes a liaison with the outside shareholders as well and gives them priority to share their valuable decision in terms of company's development. Board of directors plays role to make alignment in the organization. Alignment is the functions, structures and cultures within the organization that comes into the action with the sound corporate governance. Good environment within the organization attracts more external potential shareholders. It is always important to build up sufficient relationship with the share market and shareholders to mitigate the entity's risk. It also helps to manage the risk within the department through the risk management framework. Directors, shareholders and management get the chance to express their opinion. They can build clear and transparent accountabilities through legislative compliance and corporate reporting. The director's decision helps management to take proper action for the employee's performance. The board of directors is also responsible for any improvements or upgrades in the framework that will result in better performance. Overall, Corporate governance will help to concrete a good anticipation for the organization. Anticipation is the individual's performance, intervention and internal control mechanism. On the other aspect, development comes through the exact risk mitigation and proper hierarchal decision.

As all the elements in the framework perform in an integrated chain, financial crisis and risk are minimized, and transparency is ensured that results in a sound, efficient corporate market.

\subsection{Definition of Corporate Governance}

The word corporate is defined as a part of the economies which is made up by the companies whereas "governance" indicates mechanism to govern the companies. Corporate governance has become an extensive term in the business world. It has direct or indirect impact on the financial process (lending and borrowing) of an organization. Corporate governance makes procession with all the departments in a company. It emphasizes on authority, accountability, stewardship (responsibilities of management), leadership, direction and control (Commonwealth Department of the Australian Prime Minister, 2009). In simpler terms, corporate governance is the mechanism to facilitate entity's longevity with the proper direction and maintain internal control for mitigating risk. It also signifies to create leadership through the strategic decisions and exact authorization power. All the financial institutions like banks, insurance companies they have a proper emphasis for corporate governance. If we talk about Bangladesh Bank, the central bank of Bangladesh has a vital role to establish corporate governance environment for all commercial banks with its accountability.

\section{Background of the Study}

\subsection{History of Corporate Governance}

The Wall Street crash of 1929 have significant role in the construction of corporate governance theory. After the immediate result of that crisis some scholars such as Adolf Augustus Berle, Edwin Dodd and Gardiner Means had taken the first initiative to control the financial crisis. In the meantime, from the Chicago School of Economics, Ronal Coase introduced the idea about the organization structure and its formal behavior. Their initiative had made a great change in economy and help to constitute this theory of corporate governance. Capitalism at the beginning of $21 \mathrm{st}$ century was a great issue in the global economy. In America, capitalism was a method where many corporations competed with each other. In this broad, capitalist market corruption and inequality was a great issue. The business scholars created a framework and started to maintain it within the business organization. As a result a shape of corporate governance had been established at 21 st century. In the 1980 s, the theory got its fundamental base after the introduction of the principal-agent problem by two scholars Eugene Fama and Michael Jensen to understand the role of corporate governance (Kathleen Eizenhardt, 1989).

In Bangladesh, the financial institutions like banking and non-banking institutions have been contributing their role from then onwards. All the regulations and ownership of banks had been carried out by the government of People's Republic of Bangladesh till 1982. The mechanism of 'ownership reform' measurement started nearly 1984. At that state, there were only two banks out of six were denationalized and non-private banks got the chance to carry out their operations. From the period of 1990's the corporate governance got the exact system in the financial institutions in our country both privately and publicly. Despite, the expansion of banking sector, there were remarkable inefficiency in the operation of the banks (Sayeed, Raquib, 1999). The sectors faced some problems such as declining profitability, provision and capital shortfalls, default asset quality, corruption by political parties, increasing nonperforming assets, excessive intermediation by the government and low recovery rate due to improper use of corporate governance role.

Moreover, the financial crisis of 2008-2009 had made the real constitutions to develop the corporate governance and its further demonstration to mitigate the financial crisis. The corporate governance has been playing its own role throughout the world but it is yet to develop in Bangladesh for some unrest and biased environment.

\subsection{Parties to Corporate Governance}

The top level management implementation is the main key of corporate governance. There are various important parties such as the board of directors, managers, shareholders, creditors, auditors, regulators, and other stakeholders. Not only the hierarchy level but also the subordinates are taking 
more actions to build up company's goodwill.

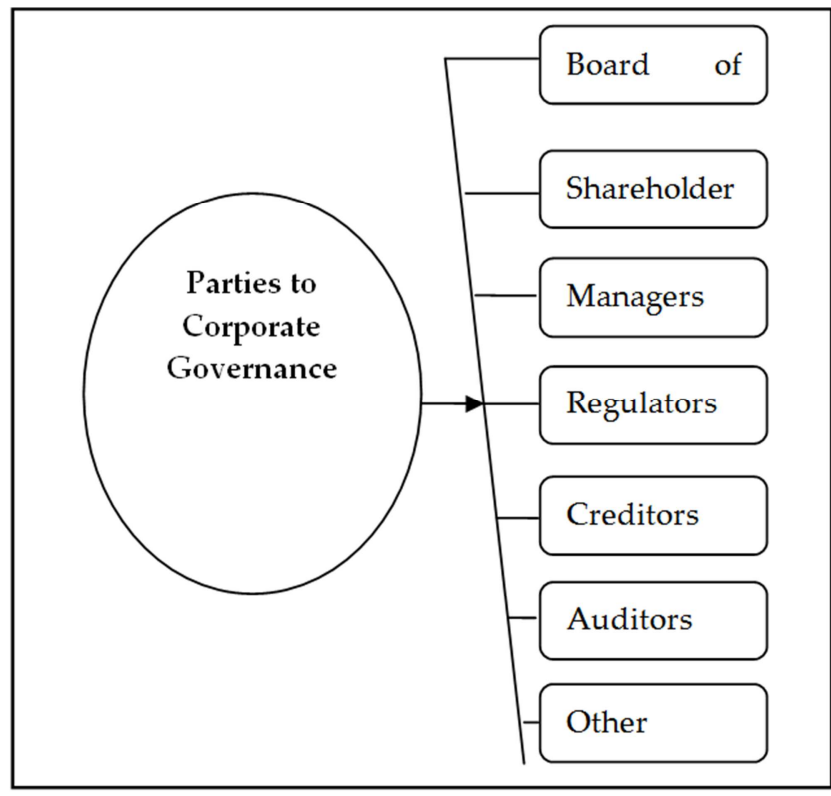

Figure 2. Parties to Corporate Governance.

A financial institution can increase its face value with proper utilization of corporate governance. Board of directors put themselves in an utmost level. They can devise the rules and regulations and take the highest possible decision. In financial institutions it is very important to make regular reviews. The board of directors can ask for general meetings to inform all shareholders before making any changes for the organizations betterment. Moreover, they may provide directions to the management for implanting any change. Shareholders are also an important part of corporate governance. Shareholders buy the share and they become a part of the company. Therefore, they are entitled to provide their comments as well. Good regulatory factors and proper acceptability will attract more share purchasers and will mitigate risk of a financial institution. Creditors can provide loan with the proper authorization and for this they always consider the company's ability to repay the loan. Creditors focus directly on the corporate governance. They can also get help from the independent auditor, who actually does the proper internal evaluation for any organization. So the auditors, creditors, and overall stakeholders (suppliers, union and distributors) are the main concern of corporate governance.

\subsection{Principles of Corporate Governance}

Corporate governance has its own view of principles. Without proper planning and principles it is extremely difficult to establish an effective vision for an entity. According to the OECD reports, principles of corporate governance symbolize the general rules and regulations by which the financial and non-financial institutions are expected to operate in proper authority.

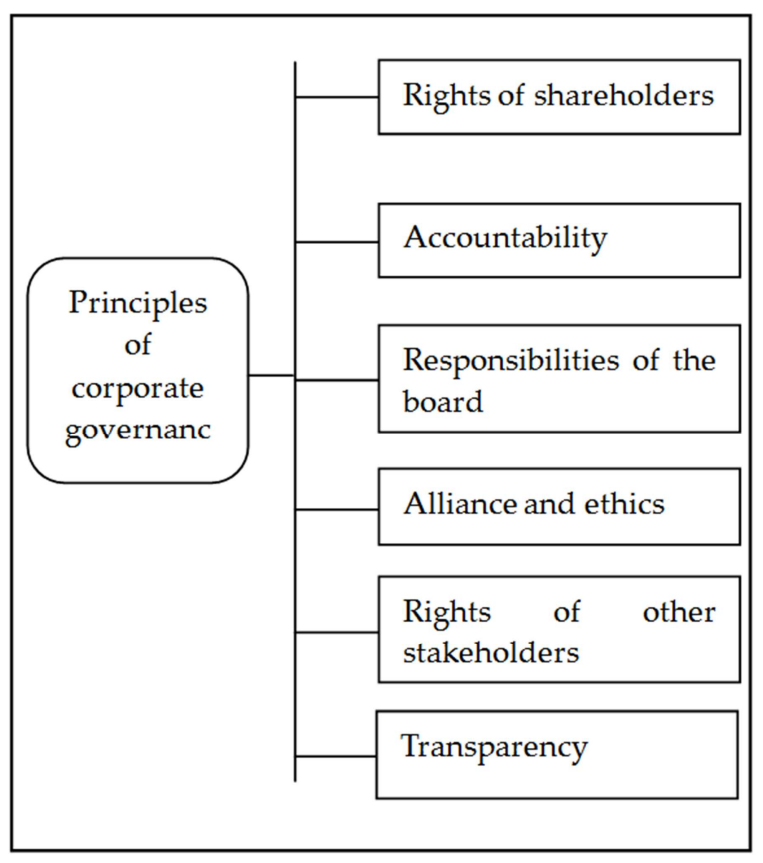

Figure 3. Principles of Corporate Governance.

In any institution whether it is financial or nonfinancial, there are almost six principles to follow in corporate governance. As it is mentioned before corporate governance is all about making the relationship within various department and implementation of plan, action, and etc. Shareholders have the significant rights for the financial institutions. Financial institutions issues share to diversify the risk. The shareholders are the part of company's ownership. According the rules of corporate governance it is mandatory to ensure the decision making rights on the behalf of shareholders.

It is highly valued that the accountability of the board of directors works as a face value of the company. The involvement of more skilled personnel with the trustee board will ensure the shareholders rights and empowerment. Their value added strategy and administration planning will ensure the control over the general executives of the entity. Accountability in financial institutions works through the acquiring reliability on it.

Responsibilities of the board work as a key role in the financial institutions. According to the corporate governance perspective it is important to have sufficient skill and knowledge efficiency to maintain the leadership over the management body. The overall trustee board including its members, chairman and vice president always maintain the rules and implement the regulations in every financial institution.

Ethics is another issue in the corporate governance of any financial institutions. It is mandatory not to be biased in terms of selecting the board members and their necessary action. Proper alignment within the financial institutions comes through the ethical constitution. Any unethical action can bring the short term benefits but it will make huge conflict in long term for the members of trustee board. Personalization works as a hyperbolic discount. 
Other relevant stakeholders like suppliers, distributors, regulators have some rights to the entity. Their responsibilities are also important. In the form of financial institutions it is important to get focus on its various media sponsors and customers contentment.

Transparency is the transmitter of an entity. It measures how efficient and effective you are. It is important to disclose the relevant information and clarify the responsibilities of any financial institutions. Every financial institution has some unique mechanism. It is their responsibility to disclose the relevant information to the customer as if they don't face deception. Ultimate transparency always brings you up in any aspect to the customer.

Rules and regulations are variables. It may change according the economics point of view and surrounding needs. Principal helps the organization to face any form of financial crisis as well.

\subsection{Why Is It Important?}

A corporation without having code of corporate governance is similar to the human without essence. Corporate governance should be the governing policy of any corporation. It can significantly enhance the entity's accountability. Corporate governance will works as an indicator to avoid any decisive disaster. In modern age, to manage the corporation effectively; entities require not only good inner governance but also resonance institutional atmosphere.

"The relationship between ownership and management is the basis of the modern corporation. Moreover, it leads to specialization of tasks, risk-bearing by shareholder, strategy development and decision making by managers in an efficient way" (Hassen, 2008). It is a good example to intensify the importance of corporate governance. According the comment of Hassen, it is clearly distinguished that a corporation will turn into a grave without proper governing body.

In financial institution, all the principles regarding the corporate governance are very important, with the risk management as the top rated one. There is a huge risk in every financial institution and non-financial institution as well. Financial institutions try to mitigate the risk as much as they can. In this perspective the corporate governance will diversify the risk to the shareholders and stakeholders in some contents. The company or financial institutions can achieve the formal guarantee against the default shareholders and bankrupt employee. Scandals, frauds, civil and criminal intention always stimulate as a big factor for any corporation. If there is a well-managed governing body and proper implementation of the principles than these frauds will not subsist. This immense mechanism will increase the public eye image which will lead to acquire to gain more shareholders capital. If there is no shared policy and accountability or transparency than the entire financial entity will be corrupted and lead to financial crisis.

\subsection{Why It Is the Top Issue for Financial Institutions?}

Sometimes the financial institutions become the top rated issues in the media for their scandals and poor operational activities. Financial scandals are occurring more frequently; therefore there is a 'question mark' about the transparency and the fairness of financial institutions. Many renowned personnel are involving with bank corruption and financial fraud. There are so many relevant cause and consequences by which the corporate governance in financial institutions gets on the crest position.

Table 1. Roles of CG in Financial and Non-Financial institutions.

\begin{tabular}{lll}
\hline Substances & Role of CG in Financial inst. & Role of CG in non-financial inst. \\
\hline Business type & $\begin{array}{l}\text { Financial instruments and money or asset is the main business } \\
\text { concern. So, the entity's concern will be the external and internal } \\
\text { stuffs. }\end{array}$ & $\begin{array}{l}\text { Business concern is about product or service oriented. On } \\
\text { this aspect, customers have not highest direct involvement } \\
\text { about CG. } \\
\text { Legal issues are important for the entity's perspective not for } \\
\text { the customer view. }\end{array}$ \\
$\begin{array}{l}\text { Legal judgment } \\
\text { Transparency }\end{array}$ & $\begin{array}{l}\text { Fairness and disclose the relevant information to the customer and } \\
\text { shareholders are the most key role in financial institutions. }\end{array}$ & $\begin{array}{l}\text { In thencial institute the transparency is the concern } \\
\text { of shareholders or board of directors but the customers are } \\
\text { not goes for the inner thesis. }\end{array}$ \\
$\begin{array}{l}\text { Time frame of } \\
\text { activities }\end{array}$ & $\begin{array}{l}\text { The services of financial institution are long term oriented; therefore, } \\
\text { Customer focus is on the short term satisfaction therefore } \\
\text { the CG of these institutions must be more specific. }\end{array}$ \\
Accountability & $\begin{array}{l}\text { For being the high risk oriented business; the customers go through } \\
\text { the previous data and performances for taking decision. }\end{array}$ & $\begin{array}{l}\text { For being the less risky corporation; the present cause and } \\
\text { consequences are important. }\end{array}$ \\
\hline
\end{tabular}

The recent scandals of Hallmark and Bismillah group were a dramatic incident in Bangladesh. In this occasion banking sectors were directly involved. Moreover, the BASIC Bank and former Oriental bank were to blame for their unconventional loan disbursements on this juncture. There is a question in the public and media as well that- why this happened?

The pretty but pathetic answer is the lack of proper utilization of corporate governance in those banking financial institutions. When the bank owners or board member want to manipulate something and go beyond the principles, the unconventional situation crops up.

Apart from the banking institutions there are other financial entities where there is a lack of corporate governance activities. The condition of the capital market in Bangladesh is very inefficient. People can raise funds and express themselves as losers without any sufficient notice. Corporate personnel can raise funds and use it to repay the bank loans without any concern. These unconventional scenarios have become possible only because of the unequal 
practice of corporate governance in the capital market. When a corporation comes in the market it goes with the operations smoothly but the problems occurs in the long run. Sometimes they may shut down their enmity for the lacking of fairness. The corporate governance is the biggest factor in the financial institutions because of their fairness policy. The proper and effective corporate governance will stimulate the entity's value added anticipation

\subsection{Financial Institutions VS. Non-financial Institutions}

The banking and non-banking financial institutions have been observed very deeply for the last few decades because of their activities. Since the financial crisis of 2008-2009, there are several proposed and recommends for overcoming the similar catastrophe (Hamid, 2012). The importance of corporate governance has been getting a big admiration from then. There are specific distinguishes on the corporate governance of financial institution and non-financial institutions.

The substances for being differentiated are: type of organization, legal judgment, transparency, time frame of activities and accountability.

People have less faith about the financial institutions and have high consciousness about their activities. Therefore, the role of corporate governance is far more different between the financial and non-financial institutions. In the financial entity's the action of board of directors and their legal factors are given the most emphasis. On the opposite, the nonfinancial institution faces less critical issues. Customer can buy the product only from the outlet without taking concern the direct operations of corporate governance. All these make the differences the corporate governance of financial institutions from non-financial institutions.

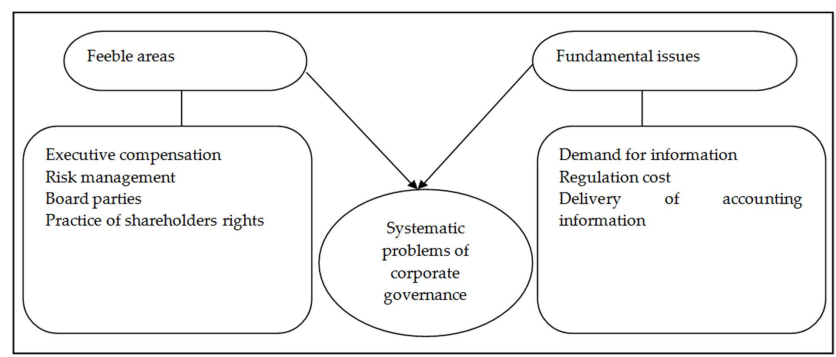

Figure 4. Systematic Problems of Corporate Governance.

\subsection{Systematic Problem of Corporate Governance}

Systemic problems can be best defined as difficult issues in the systems which are within controllable reach. In economic and financial perspective there is some existence of systematic problem about the corporate governance implementation. Corporate governance is well established from last two decades but did not solve its basic critical issues. This mechanism worked ineffectively to stop share price manipulation.

The economic crisis in 2008 is a vital one to explain the systematic problems of corporate governance. The US banks and financial institutions took extreme risk for short term profit maximization. In some extent, the corporate governance is fully long term desired but the US fed focuses on short term. The unsolved bank and financial institutions crisis is still a high issue for systematic problem of corporate governance.

The most important point is about the inadequate execution of corporate governance principles while the present corporate governance frameworks are working well (OECD, 2009).

According to the OECD, there are four feeble areas (executive compensation, risk management, board practices and the exercise of shareholder rights) for which financial crisis may occur. The manipulation of any area of these may create systematic problem of corporate governance.

There are three fundamental issues for the systematic problem of corporate governance: demand for information, regulation costs, and deliver of accounting information. There is a voting power rights for the shareholders within the organization. Therefore, they need some sort of detail information which may lead to the insecure resolutions for the trustee board.

There is another barrier that is the regulation cost of information. The financial market should be efficient and in an efficient market they have to maintain the all relevant information to disclose for the shareholders. This is highly cost oriented for the long term. Supply of audited accounting information is the key role to provide the directors activities in future. They can anticipate and provide the direction according it. This accounting information can be manipulated by the internal auditors and accounts personnel.

When compared with feeble areas of the systemic problems of corporate governance, the fundamental issues are much more integrated within the system. These are also within manageable influence, which therefore should be carefully solved by the board to minimize the problems associated with corporate governance.

It is well known that mitigation of total risk is almost near to impossible because of the presence of huge unsystematic risks. However, if the risks which can be buried are possible to do so then that should be done to reduce the overall total risk through corporate governance.

\subsection{Mechanism and Control}

Effective corporate governance always helps a corporation to reach its mission and vision; it also helps to stimulate the business strategy as well as the proper management mechanism (corporate governance Mechanism, 2009). The mechanism and control of corporate governance have been maintaining enormous consequences in financial institutions. The structure of admirable corporate governance is always enclosed with mechanisms.

There are usually three mechanisms: internal mechanism, external mechanism and control and independent audit. Every single element of a specific mechanism has a significant effect in both internal and external activities of a financial institutions as well as any effective corporation. Independent audit must make a bridge between these two tools of control. 


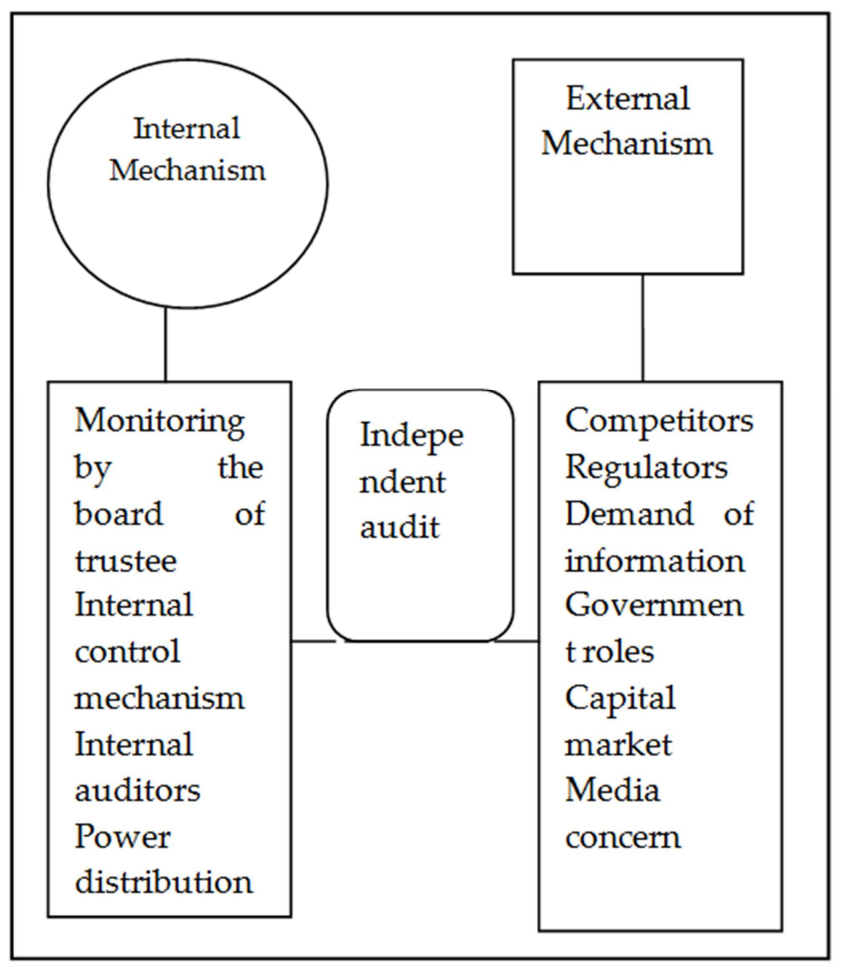

Figure 5. Mechanisms of control of Corporate Governance.

Internal mechanism of corporate governance focuses on the board of directors' actions including the policy making, rewards for the top management and safeguard against the invested capital. The frequent meetings must be arranged for tracing problems and make the strategies to conquer it. Implementation of the policies according to the direction is the work of management body. In corporate governance, internal auditor focuses on the accounts responsibility for all relevant actions. Power distribution means to change the board members and president within the shareholders voting power. It will also be beneficial to trim down corruption. The employees are expected to get the reward for their best performance which leads to reduce the margin of error in the organization.

External mechanism such as competitor's new business tricks and government tax policy will surely change the existing strategy for a financial corporation. Moreover, media makes entities sway either in a smooth direction or in rough consequences on the basis of its performance.

Independent auditor's responsibility is to maintain the exact audit to deliver the information for internal and external users which surely increase the financial transparency. The mechanism and control of corporate governance have an effect of entity's financial performances.

There is a negative relation between the financial performance and the external or governmental attributes. According the graphical view, the financial performance of firm $\mathrm{A}$ is high because of less governmental attributes but when the governmental or external issues are high than the financial performance is getting lower. There are some cause and effect of this statement. Firstly, when the financial institutions have a very big board of trustee and a large body of general entity then it is tough to take control over it. Moreover, the external mechanisms get more options to thesis an entity's negative deeds. Therefore, the overall financial performance gets down for maintain the collaboration.

So, it is important to give more focus on the board activities and size as well for maintaining proper institutional activities.

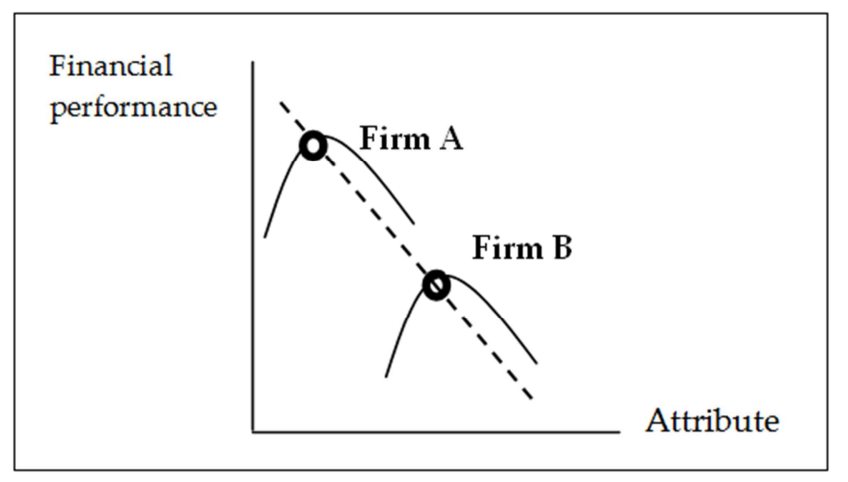

(Source: Journal of Economic literature, 2010)

Figure 6. Inverse relationship between financial performance and attributes.

\section{Boards and Financial Institutions}

None other sector has been criticized lately than the banking sector due to their role in financial crisis. Weak governance of banks is the main cause of such crisis that showed the flaw of financial market. Many studies has been done so far to find the failure of corporate governance during the crisis and result comes out like executive compensation, board's role, risk \& risk management, market discipline etc. In this section, we are focusing on (1) Board \& senior management function, what their role represent in the firm (2) Uniqueness of financial institution, (3) Board responsibility, (4) Board effectiveness (5) Boards skill \& competence (6) Board Independence.

Many authors argue that the board is the first line of defense in governance. For effective governance boards of financial institution must have the ability and willingness to challenge the management for a good dialogue to ensure company in right direction. Board members must invest sufficient time and energy to understand what risk the firms are exposed. Minton, Williamson (2010) stated that board members of larger financial institution have too many commitments that cause failure in fulfilling their responsibilities. An engaged, independent and expert board member considers that their primary responsibility is to the shareholders. Supervisors are interested in other stakeholders like creditors, depositors and public.

Valuable long term shareholders generally have the right to be presented in the board meetings. These shareholders always consider the long term success of the company. Those shareholder who do not represent the board, express their view through the elective non-executive director of the board. Financial institutions also maintain constructive relation with 
board. They recognize that shareholders are heterogeneous group and do what they desire.

\subsection{The Board, Senior Management and Oversight Functions}

(Dar es Salam, 2010) stated that board of director have the ultimate responsibility for the level of risk taken by their institutions and senior management manages the activities their institution conduct. Board members approve the overall business policies and important polices of their institution like risk taking activities, while management takes necessary steps to identify, measure, monitor and control these risks.

In good governance, board of directors have a clear view about what types of risk their institution are exposed and receive report from management about the size of the risk \& importance to their firm. The board also takes steps to understand the depth of risk their institution face and gets briefing from external auditors and external expert. This information gives the board a clear guidance regarding the level of risk exposures their institution can accept and ensure senior management implements the procedures and policies.

Senior management is responsible for implementing strategies in a way that controls the risk associated with each strategy which confirms compliance with rules and regulation. Senior management is involved in day to day activities and possesses sufficient knowledge to monitor the policies, control and risk management system are in place which ensures accountability. Senior management is also responsible for establishing awareness about high ethical standards. To fulfill these functions senior managers require understanding of banking and financial market activities and detail knowledge about what their firms do.

\subsection{The Uniqueness of Financial Institutions}

Principal agent theory states that manager, the agent may not work always in the interest of owners. It is not possible for investors to monitor everything perfectly so there is need for some mechanism which can prevent insider of a company to take advantage of the firm's profits. There are different tools available for investors. They can increase the size of the board, they can announce management based compensation and concentrated ownership. Crucial difference between financial \& non-financial firms depends on these tools which are largely affected by regulation, capital structure and business model.

According to principal agent theory managers not only prefer less risk than desired by shareholders, they also invest in the company they manage (Faleye \& Krishnan 2010). They can lose all their investment if the bank goes bankrupt. The board always aims to maximize shareholder wealth which leads to higher risk taking decision and higher chance of failure. As financial firms are more leveraged than nonfinancial firms, they fail easily. However, banks; failure have serious consequences than non-financial firm as they are in unique position of financial intermediary and payment system. The excessive risk taking nature of bank leads to more regulation than non-financial firms. Boyd and Runkle (1993) stated that big bank failure news panicked almost anyone in the industry than small one. Because, big bank failure causes macroeconomic casualties which no government wants. As a result, "bank too big to fail" receives government guarantee which is not possible for non- inancial firms.

A second difference with non-financial institution is that financial intermediaries depend on depositors funding which involves incentive based on performance. So, they take higher risk for higher revenue. But, if the investment fails then majority of the loss will be borne by the depositors. At the same time, investors cannot monitor bank managers due to high information asymmetry and co-ordination cost. (Demirguc-kunt and Detragiache, 2002). Though, investors are protected through couple of deposit insurance system it increases banks risk raking behavior as they believe their funders are protected. Some non-financial firms also take excessively risk if they are weakly capitalized but agency problems of bank arises because of deposit insurance system and government guarantee which gives bankers incentives for higher risk. As a result, role of banks and external casualties make it costly for economy at large. (Marine and Vlahu, 2011)

Last but not the least different uniqueness of financial institutions regarding corporate governance depends on structure of management compensation model and corporate control. Stockholders want management to have stock option which they believe increases the performances heavily. However Adams \& Mehran (2003) argued that stock based option works better in non-financial firms than the financial firm. Because, banks are highly leveraged institution and it should limit its stocks or it could suffer the cost of issuing debt.

Corporate control is the market for non-financial firm which can operate in friendly merger, proxy contests etc. The most important piece for corporate control is forcing manager to behave in favor of shareholders known as hostile takeover. If a firm fails to understand its potential, an outsider makes it attractive package for takeover. After acquiring, that outsider may change management which gives manager enormous power to behave in the interest of shareholders. However, this kind of scenario is unlikely in banking industry. The threat of hostile takeover by big bank of poorly performing bank is rare. Adams \& Mehran (2003) stated many reasons behind that are regulation and capital structure. Regulation imposes set of rules which gives bank power to look for alternative strategies or seeking alternative bidders. Because of capital structures acquirer need to borrow huge amount of money for acquiring investment, but bank may be unwilling to provide any money as they are already highly leveraged. Moreover, it is almost impossible of a hostile takeover if the bank is private and not traded in the secondary market.

\subsection{Board Responsibilities}

Board of directors plays an important role in keeping balance between governance and interest of stakeholders. 
They focus on strategy, risk- governance and the quality of management. Board also looks up to supervisors as valuable source of industry intelligence which provides information about what other financial institution are practicing. The board is considered an active monitor of a company's monitor system (Kiel and Nicholson, 2003). A board's monitoring reduces agency costs and safeguards the interest of shareholders (Jensen and Meckling, 1976).

"Group of Thirty", a US based firm recently did a study on "New Paradigm of financial institution boards and supervisors" and stated that an effective board takes some specific action to fulfill their responsibility. These are:

- Board of financial intuitions have members who have current relationship with supervisors

- Board understands how their structure helps or hinders relation with supervisors.

- Board focuses on their own effectiveness and that selfassessment grounded in an understanding and demonstration of effective board behaviors.

- Board becomes proactive in engaging supervisors in formal discussion about board effectiveness.

\subsection{Board Effectiveness}

Board effectiveness depends on board size, attendance and business. It is familiar that a small group of members' board is more effective in decision making process (Jakob \& Razvan 2012). Directors with more outside directorship may bring more information but at the same time they will be not attending meetings because of time constraint and become less effective. In the management literature, effective board means members co-operating each other, sharing information, monitoring the merit of alternative decision \& reaching a reasoning decision (Forbes \& Milliken 1999). According to Pathan $(2009$, p.1340) "the board is the first line of defense to the shareholders against the management."

Board size affects a firm's performance as Dalton (1999) stated that "the large board may get beneficial because they increase the knowledge pool and resources available to the organization." In a complex business model it can be both advisory and monitoring role. But, boards members often fail to take advantage of others view \& do not share their own information with other members. Even if, large board brings huge expertise, it also increases the decision making process. Several studies have been done to understand the board size and board's performance. Beltratti and Stultz (2012) performed a study to find out the relation between corporate governance and banks performance during the credit crisis (July 2007 -December 2008) in 164 bank with asset more than 50 billion. They found that shareholder friendly board (small) had less buy and hold returns during the crisis. On the other hand, Adams (2012) mentioned in her report that of 89 banks in her sample, 56 received bail-out fund who had a larger board. If risky bankers were the ones bailed out it means their larger boards took more risk. In another study done by Faleye and Krishnan (2010) it is reasoned that banks with smaller board approve less junky and speculative loans.

Only few studies examine board attendance and firm's performance. Directors' duty is to obtain as much information they can about the market, government regulation, future trends, industry change and sharing this information through their attendance on board meetings. The larger board tend to have free-ride behavior as they give less importance to these meetings.(Adams \& Ferreira, 2012) stated on their report (using a sample of 5707 directorship from 35 large US banks) that board size is significantly related to attendance. They also find that incentives for attendance, like meeting fees have huge effects on their attendance behavior.

Because directors have directorship, they are more distracted and cannot be an effective monitor. Though it also argued that busy, outside board members contain more knowledge and expertise which increases firm's performance. As they sit on different boards they possess and provide specific industry knowledge than who do not. These findings are not consistent with Grove (2011) report that who found busyness is related to ROA not to loan quality.

\subsection{Board Skills and Competencies}

Managing board have become a difficult task as bank grows bigger and more complex, increases the activities of members as they need more knowledge and skill to understand the task (Mehran,2011). For example, the Dutch banking code states that "Each director's expertise plays an important role in risk management. They must be capable of evaluating bank's long term vision, policy to maintain balanced view about the basic risks involved. Each member of the supervisory board must have specific expertise to do his/her assigned role. The relationship between directors' expertise \& bank's performance are mixed. In one side, having experienced and knowledgeable members is important for banking firms as they lead to more efficient risk taking decision. On other hand, this kind of board assures both government and shareholders which encourage taking more risk involving action. Another study found that relationship between expertise and performance and risktaking may be different at different time period.

\subsection{Board Independence}

A widely researched question is how directors who have no ties with the financial, firm or management affects the performance. Devries (2010) defended this from creditors' view stating that independent director are more focused on management training rather than short term objectives related to their compensation. Banking industry became competitive for independent director \& making them concerned about their reputation (Pathan, 2009). Since, they are in perfect place to discipline management at the same time they are effective in reducing agency conflicts. However, Adams and Ferreira (2007) argues that independent directors hurt advisory role. This happens because CEO report to independent board members with less information. Value of monitoring and advice declines as independence increases. In addition, effectiveness of board members depends on their 
ability. Wagner (2011) pointed that CEO can control the firm if board has lack of ability or knowledge do they require function. Although, outside directors may be more effective in management they may lack of knowledge of the internal banking works, and also the financial expertise to understand the bank complex processes which involves potential risk. Several studies mention that in financial institution outside board members has no financial experience (Milton, 2010). The studies on "Bank performance \& board independence" by Hermalin and Weisbach (1998) said that board must take the decision of CEO. It depends on firm's performance whether CEO is replaced or not. Poor performance gives CEO signal that board may replace him. An exception study done by Cornett (2010) about corporate governance mechanism and bank's performance during the financial crisis stated that firm with independent board did well. An important issue, when it comes to external directors is their role. Mongiardino (2011) examines during the financial crisis whether performance of bank is better with more independence in board committees. They used data from G8 nation's financial institution and found that independence in auditing and risk committee helped improve risk performance. According to Mongiardino and Plath (2010) risk governance requires a board level risk committee, member of those committee are independent and CEO should be in executive board.

\section{Risk and Risk Management}

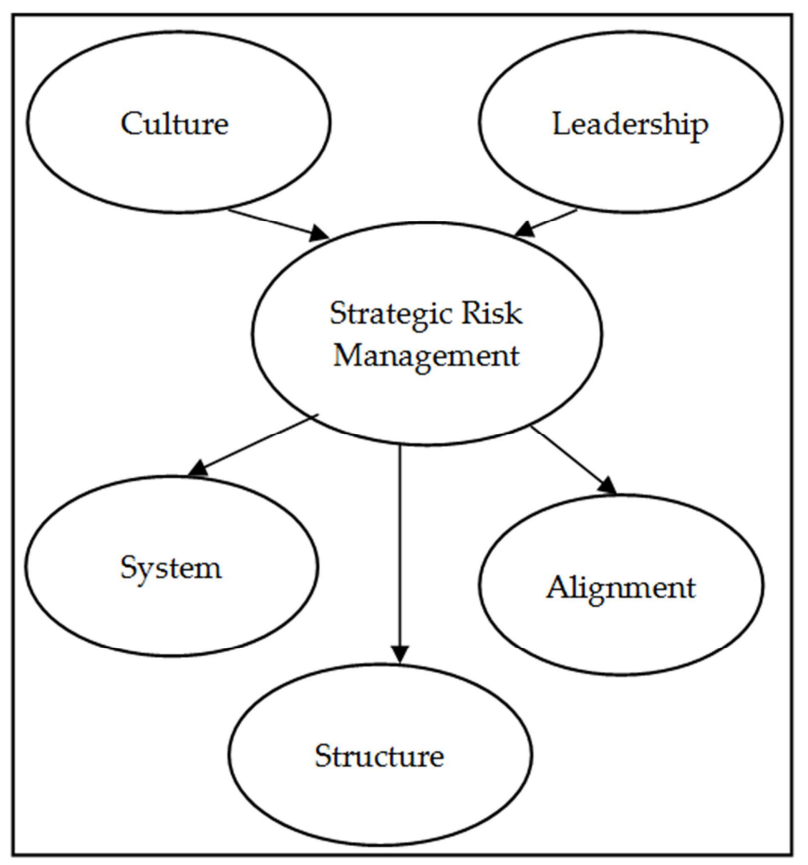

Figure 7. Risk Management Model.

Risk is best defined as the chances of some or all of the initial investment being lost because actual return was different than expected. "The Institute of Risk Management" argues that risk management is a systemic process that involves understanding, evaluation, and acknowledging the risks to maximize the chances of objectives being achieved and ensuring organizations, individuals, and communities are sustainable. An effective risk management system requires an informed understanding of relevant risks, a valuation of their relative priority and a laborious approach to monitoring and controlling them (Investopedia, 2015).

Hossain (2008) states that the vision of corporate governance being incorporated in Bangladesh is conveying a change to the current system and which may carry many risks as well. Therefore, a strong risk management and mitigation system is necessary that will ensure a smooth transfer to the corporate governance system (Hossain, 2008). Drew, Kelly and Kendrick have drawn five elements that should be explored and considered when trying to minimize the risk of and with CG. According to them, an effective risk management system must be distinctively broad to eliminate strategic failures (Drew et al, 2006).

\subsection{Culture}

Schein (1996) states that culture has the most powerful influences on decisions and strategies undertaken by an organization. Organizational cultures that promote arrogance and secrecy are much more prone to deny failure and create catastrophic consequences. Professors Baucus and Near (1991) commented: “A corporation's culture can predispose its members to behave illegally. As the relationship between prior violations and illegal behavior appears to indicate, some firms have a culture that reinforces illegal activity. Firms may also socialize employees to engage in illegal acts as a part of their normal job duties." Some cultural aspects that result in poor governance and broken risk management include unethical behavior, excessive internal rivalry, secretiveness, and oppression of people who raise their voices. According to figure 7, culture is knotted with leadership, alignment, systems, and organizational structure. Culture can be an effective source to strategic risk management and a foundation of competitive advantage. Professor Schein's (1996) considers that organization should emphasize on the power its culture can have in influencing its values and behaviors. Corporate culture with strong moral values that follow reasonable ethics encourages candor and integrity, and in turn creates a balance with these elements and reasonable levels of risk- taking. Hamilton \& Kashlak (1999) states it is not possible to detach organizational culture from national culture, and international firms should cogitate national cultural differences before defining risk control systems.

\subsection{Leadership}

Positive, charismatic leadership qualities can have a significant influence on organizational performance. Such leadership skills can ease ethical crises and promote risk management. In fact, many studies have shown that when under the leadership of a skillful director, managers tend to become less risk averse and investors feel more confident to purchase additional stock options of the company. Professor Sankar (2003) stresses on the morale and character of the leader, and his core 
values of integrity, trust, truthfulness, and human dignity as elements of excellent leadership values that ensure effective alignment of culture with leadership. Drew et al suggests that the boards of directors can advance leadership skills and risk management by integrating crucial risk management activities in a corporate department by creating a balance between organizational competencies and the experience of executive teams. It is up to the leaders and board members of the organization to improve the levels of governance and standards of risk management. A suitable leadership style is equally significant for developing ethical values in culture and organizational building (Drew et al, 2006).

\subsection{Alignment}

Drew et al notes that a number of important aspects of alignment are present between organizational risk management, strategic risk management, and governance. Misalignment can occur if an organizational changes its structure frequently, if governance system of the firm fails, and if the strategic perspective is not taken into account when making decisions based on risk. For better chances of success corporate tactics should be aligned with the organization's risk management ability and its appetite for risk (Drew et al, 2006). Professor Labovitz (2005) highlights that appropriate leadership styles should be aligned with organizational culture, its systems, its structure, and its attitude towards risk. However Drew et al argues that alignment cannot be easily achieved because many organizations scuffle to manage interfaces between external and internal audit, regulatory compliance, and risk management functions. Proper alignment demands conflicts between functions to be regularly recognized and acknowledged.

\subsection{System}

Professor Farrell (2004) suggests that companies should familiarize an enterprise-broadened risk management system that includes financial, legal, and operational aspects which have an effect on the strategic goals of the organization. $\mathrm{He}$ emphasized that the role of internal auditors is crucial in this category because of the linkage between internal control and overall risk management authority for organizational goal achievement. Professor Simons (1995) states that corporations should use control systems as strategic tools to support the future development of the organization. He also highlights how control systems can be used for creating and improving organizational energy, and promotes innovation and growth. Drew et al argues that an effective control system allows the directors to assess the appropriateness of organizational risk management. To improve risk management, firms should consider the capability of control system to identify, analyze, forecast, and manage a wide variety of business and strategic risks (Drew et al, 2006).

\subsection{Structure}

Drew et al states that in the modern corporate world, board members should decide upon the structure of the organizational control and hierarchy for the sake of good governance and risk management. There should be the clear scope of independent thinking without conflicts among the directors. Some examples of corporate scandals suggest that there is always the possibility of the abuse of power at the top management. However, experts opt for a decentralized and democratic leadership approach to oppose such abuse (Drew et al, 2006). Professor Collins (1997) gives a compelling preference to participatory management systems over autocratic structures. Drew et al continues their argument saying that even for corporate giants, adjusting structural changes with governance reforms and risk management is a challenge. Proper implementation of a structure requires ensuring effective communication among organization, because structure has a direct influence on culture by redefining individual organizational roles. Drew at al concludes that alignment of appropriate cultural norms, leadership, and systems with the right structure can significantly boost the risk management abilities of the firm (Drew et al. 2006).

Above we have discussed the five elements of risk management tools that organization can adopt to mitigate strategic risks of corporate governance, as explored by Drew et al (2006). As argued by Hossain (2008) that the cultural aspect of the model is directly applicable to the model of corporate governance if implemented in a financial institution in Bangladesh, we believe that the other four elements of the model can have a significant influence as well in the risk and risk management of corporate governance.

\section{Market Discipline}

"Market discipline" is the rules and regulations present in the market and monitored by regulatory systems to promote transparency and disclosure of risks and information of a business or entity. Market discipline works best in harmony with regulatory systems by encouraging the release of timely and accurate information regarding a company's assets, liabilities, and general financial information which in turn results in safety and soundness of the market.

Witherell-OECD (2003) stated in his concluding remarks of corporate governance principles that market discipline and transparency are of central importance to the implementation of the vigorous corporate governance practices that in turn creates a stable market for investors. Establishing a framework by policy makers of transparency, market discipline and corporate governance means these three elements act in a positive, coherent way that strengthens market integrity and economic performance (Witherell OECD, 2003).

\subsection{Shareholders' Rights and Disclosure of Information}

A shareholder can be an individual or an institution that legally buy and own share of stock of a public corporation which represent part ownership of a company. Nam (2004) explains that an orthodox corporate governance model views 
the shareholders of the corporation as the principal, and this makes the objective of the management to maximize the interest of the shareholders. Depending on the class of stock, shareholders are given certain rights and privileges to participate directly in monitoring their firms even though they have entrusted the management to guide and monitor the organization towards success. According to OECD (1999), the basic rights of shareholders include been informed of relevant corporate information timely and regular, being able to participate in voting at general shareholders' meetings and the election of board members. Shareholder rights also explain the legal position of shareholders in a corporation, the loopholes and precautions that can be utilized, and the procedures that has to be followed if things go south. Nam(2004) notes that after the economic meltdown, a number of Asian countries adopted further requirements targeted to delivering more powerful protection for the rights of minority shareholders.

Extent of effective participation of shareholders in the decision-making activities

According OECD (1999), the prime right that shareholders have is the allowance to vote at meetings, and all shareholders of the same class of stock should be treated in the similar manner. Becht, Bolton, and Roell (2002); Harm (2000) believes that there should be no foremost restrictions deterring the participation of shareholders in decision making in anyway. There should be other ways of attendance in meetings if shareholders cannot be physically present such as proxy and mail-voting (Becht, Bolton, and Roell, 2002; Harm, 2000). Haque, Jalil and Naz (2007) notes that the phone can be another tool of participation if shareholders are unable to participate by presence. Nam (2004) states that other restraints of manners of notice, registration requirement, and timing and venue issues should also be dealt with and kept to a minimal level. The corporation should provide the shareholders with plenty of adequate and relevant information regarding agenda meetings, comments and issues raised at meetings.

The right to elect directors and other rights

Nam (2004) believes that the most important role of shareholders in the annual general meetings is their right to elect the board members of the corporation. Shareholders' meeting cannot be held that often, that is why it is up to the board members to make most of the major corporate decisions on behalf of the shareholders and other stakeholders. Apposite consideration involving such voting should include to fully informing the shareholders about the candidates for directorships before election, if it is possible to propose candidates of their own choice, and if cumulative voting is possible. Other rights of shareholders include preemptive rights of minority shareholders to new share issues, approval of related-party transactions, mandatory bid requirements, and dissenters' rights. Minority shareholders should also have the right to inspect a firm's accounting records, corporate affairs, and property. They should be able to put a request to hold a shareholders' meeting without much hassle (Nam 2004).
Shareholder Actions against Directors if fiduciary duties are breached

Black (2001) identifies duty of corporate boards towards shareholders as two fiduciary ones: duty of loyalty and duty of care. Black continues to explain the two duties saying that duty of loyalty involves directors acting in the company's interests and not of their own, and duty of care requires directors to do their best in making good decisions (Black 2001). Nam (2004) notes that if by any chance the directors are not performing their fiduciary duties effectively, shareholders have the right to take action against such inconsistency in the form of petition for dismissal of directors and auditors or the ban of directors' illegal activities if any, and the file of lawsuits for compensation of damages suffered by the shareholders. OECED (2003) notes that regulatory authorities and government bodies should be equipped to counter any such unethical or unfair practices such s insider trading, price manipulation, and unfair relatedparty transaction. Nam (2004) concludes his argument stating that shareholders should be able to identify prime ownership and control of the firm if they want to be more cautious against fiduciary violations by the directors.

\subsection{Public Disclosures and Transparencies}

Nam (2004) believes that an essential component of marketbased monitoring of companies is the disclosure of information. Proper disclosure of information ensures transparency, which in turn protects the corporation's investors, and thereby boosts up the confidence of future investors. OECD (1999) states that disclosure of information should be timely, accurate and informative. Any information that could hamper shareholders' interests should be immediately disclosed (OECD 1999). However, Nam (2004) states that because formal business reports are prepared semiannually or annually, report of time sensitive information should occur in the company's website without any delay. Nam continues to emphasize on modern technology for updated information dissemination such as the Internet and other cost-effective technologies. Nam concludes his argument stating that companies must adopt internationally recognized accounting and audit standards and maintain and independence of the audit process (Nam 2004).

Haque, Jalil and Naz (2007) did an analysis on corporate governance present in Public Limited Companies- Financial, Non-Financial Institutions and State Owned Enterprises in Bangladesh. In their findings, they concluded that although SEC of Bangladesh and other regulatory bodies have made disclosure of crucial information mandatory (such as directors' selling and buying shares in their company, background and remuneration of directors, etc.), organizations in all three sectors of their study need to improve their procedures of disclosures because the key objective of disclosure of information is to improve transparency. Haque, Jalil and Naz believes that rather than considering it as a requirement to disclose relevant and important corporate information to the shareholders, organizations should embrace the compliance which in turn will improve potential investor confidence in the future. They concluded that transparency of State Owned 
Enterprises is much better than public limited companies, both financial and non-financial institutions. Therefore, the latter should introduce and develop the culture of information disclosure to the public in most effective manners (Haque, Jalil and Naz, 2007).

\section{Prior Analysis and Correlation}

To make a correlation with the data and information collected through primary survey with previous analysis done by others, we have selected the journal paper "State of Corporate Governance in Bangladesh: Analysis of Public Limited Companies-Financial, Non-Financial Institutions and State Owned Enterprises" by Dr. A.K Enamul Haque, Mohammad Behroz and Jalil Farha Naz published in 2007. In their analysis part of corporate governance in financial institutions, they have focused ondata from different banksof Bangladesh and drew a correlation between data also collected from the financial sector and non-financial and state owned enterprises. Since our study is focused only on financial sector's corporate governance, we shall concentrate on that part of their study only and try to draw our own correlation with our collected data. (For further clarification on the questions asked, it is recommended to consult the questionnaire present in the appendix)

General information of the corporation

- We established the ownership structure of their company.

Table 2. Ownership structure.

\begin{tabular}{|c|c|}
\hline $\begin{array}{l}\text { Financial } \\
\text { Institutions }\end{array}$ & Ownership structure \\
\hline DBH & $\begin{array}{l}\text { Ownership is fairly disseminated with no controlling } \\
\text { shareholder }\end{array}$ \\
\hline EBL & $\begin{array}{l}\text { Two or more shareholders collectively control the } \\
\text { company }\end{array}$ \\
\hline CITY BANK & $36.91 \%$ local and $63.09 \%$ foreign shareholders \\
\hline
\end{tabular}

- We found out that all three financial institutions are not controlled or owned by the government at all.

- We focused on relationship the company's CEO has with their founder or biggest shareholder. All three financial institutions stated that their CEO is professional manager to the company.

- For the ownership/control structure of the biggest creditor bank of their company, all three financial institutions stated that such control structure belong with a business group not related to the firm.

Shareholder rights and disclosure of information

- Below is the ease of voting procedure by shareholders in the meetings mentioned by the surveyed institutions.

Table 3. Ease of voting

\begin{tabular}{ll}
\hline Financial Institutions & Ease of voting \\
\hline DBH & Proxy allowed \\
EBL & Proxy allowed \\
CITY BANK & Presence required \\
\hline
\end{tabular}

- In Haq, Behroz and Naz's study, they have also came across a similar finding, where they stated that most of the shareholders either are physically present or use a proxy for voting.

- We asked further 10 opinion based questions assembled in Likert format giving 5 to strongly agreed, 4 to moderately agree, 3 to agree, 2 to disagree, and 1 to strongly disagree.

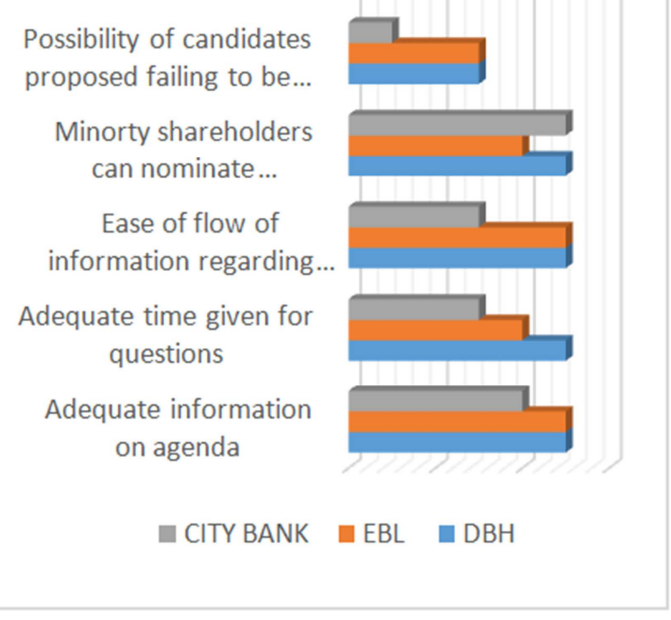

Figure 8. Shareholder Rights.

- In Haq, Behroz and Naz's study, they have found that only information regarding equity is valued. However, in our analysis we can see that all other factors are been given importance as well.

Disclosure and Transparency

In a tabular format, the data for company's tools for disclosure of information regarding specific material were recorded for analysis as such. (Web: Company's Web Page AR: Annual Report RR: Report to regulatory agencies No: No disclosure)

Table 4. Disclosure if information.

\begin{tabular}{|c|c|c|c|c|}
\hline & Web & $\mathbf{A R}$ & $\mathbf{R R}$ & No \\
\hline $\begin{array}{l}\text { Directors' selling or } \\
\text { buying shares }\end{array}$ & & & $\mathrm{DBH}$ & $\begin{array}{l}\text { EBL } \\
\text { CITY BANK }\end{array}$ \\
\hline Resume of directors & $\begin{array}{l}\text { DBH } \\
\text { CITY BANK }\end{array}$ & $\mathrm{DBH}$ & & EBL \\
\hline $\begin{array}{l}\text { Remuneration of } \\
\text { directors }\end{array}$ & & $\begin{array}{l}\text { EBL } \\
\text { DBH }\end{array}$ & & CITY BANK \\
\hline $\begin{array}{l}\text { Fees paid to } \\
\text { external parties }\end{array}$ & & $\mathrm{DBH}$ & & $\begin{array}{l}\text { EBL } \\
\text { CITY BANK }\end{array}$ \\
\hline $\begin{array}{l}\text { Policies on risk } \\
\text { management }\end{array}$ & CITY BANK & $\mathrm{DBH}$ & & EBL \\
\hline $\begin{array}{l}\text { Possible changes in } \\
\text { ownership }\end{array}$ & $\begin{array}{l}\text { DBH } \\
\text { CITY BANK }\end{array}$ & $\mathrm{DBH}$ & $\mathrm{DBH}$ & EBL \\
\hline $\begin{array}{l}\text { Explicit corporate } \\
\text { governance rules } \\
\text { and vision }\end{array}$ & & $\mathrm{DBH}$ & & $\begin{array}{l}\text { EBL } \\
\text { CITY BANK }\end{array}$ \\
\hline Semi-annual reports & $\mathrm{DBH}$ & $\begin{array}{l}\text { EBL } \\
\text { CITY BANK }\end{array}$ & $\mathrm{DBH}$ & \\
\hline $\begin{array}{l}\text { Quarterly financial } \\
\text { statements }\end{array}$ & $\begin{array}{l}\text { DBH } \\
\text { CITY BANK }\end{array}$ & & $\mathrm{DBH}$ & EBL \\
\hline
\end{tabular}


As we can see from above, from the three surveyed financial institutions two of them have a tendency to not disclose information regarding some corporate aspects. This also coincides with Haq, Behroz and Naz's study where they have concluded that around $37 \%$ of their surveyed banks do not disclose sensitive information as well.

\section{Effectiveness of the Board}

To evaluate the effectiveness of the board in regard to corporate governance, we first analyzed the overall board population and composition.

Table 5. Population and composition of board of directors.

\begin{tabular}{llll}
\hline $\begin{array}{l}\text { Financial } \\
\text { Institutions }\end{array}$ & $\begin{array}{l}\text { Total } \\
\text { directors }\end{array}$ & $\begin{array}{l}\text { Outside } \\
\text { directors }\end{array}$ & $\begin{array}{l}\text { Independent } \\
\text { Directors }\end{array}$ \\
\hline DBH & 10 & 1 & 2 \\
EBL & 9 & 0 & 9 \\
CITY BANK & 15 & 0 & 1 \\
\hline
\end{tabular}

As we can see that the board of directors in number ranges from 9 to 15, with an exception of all 9 directors as independent directors for one of the financial institutions. Other information regarding the board of all three financial institutions surveyed concluded that, a stock option is given to CEO, independent directors actively participate in meetings, the company frequently hires external auditor to conduct reviews of CEO's work, and the company occasionally or never provides training opportunities for the directors beyond what is mandatory. All three surveyed financial institutions stated that their CEO's performance is routinely evaluated, which also matches with Haq, Behroz and Naz's findings, where they concluded that financial sector's CEOs' performance are regularly reviewed.

For the last part of our survey, we gathered info on how many board meetings were held last year along with their attendance.

Table 6. No of meetings and average attendance.

\begin{tabular}{lll}
\hline Financial Institutions & No of meetings & Average attendance \% \\
\hline DBH & $4-5$ times & $80-90$ \\
EBL & $6-7$ times & $60-70$ \\
CITY BANK & 8 times or more & 90 \\
\hline
\end{tabular}

From the table above, it can be noted that number of board meetings were held frequently last year and the average attendance was at least 70\%. Haq, Behroz and Naz's findings also state the same, where they established that around $100 \%$ of the members attended all meetings.

We have drafted a correlation with prior analysis where we came to see that although in most cases our analysis matches with the one done previously, in some cases a negative correlation was found. This may be to the fact that the study with which we have compared our findings was done in 2007 whereas our data has been collected in 2015. A much can change in these seven years, such as an improvement in the corporate governance practices in the financial sector of our country's economy. The findings of our study are therefore presented in the next chapter.

\section{Findings}

As mentioned previously, our study is focused on three financial institutions of Bangladesh in Dhaka city. Through a structured questionnaire, we have collected and analyzed data and information of these three financial institutions regarding their corporate governance practices. In the following according to our data analysis, our findings are presented.

Shareholder rights and disclosure of information

In all three financial institutors interviewed it is seen that shareholders can vote with ease where the usage of proxies if necessary are allowed in two out of the three institutions. For other shareholder rights such as agenda information and time allowance for discussion of shareholders' issues, it can be seen that all three institutions follow and value these aspects, which in turn shows a strong code of conduct of corporate governance.

Disclosure and Transparency

The prime objective of disclosure of information is to ensure that proper transparency exist in the corporate sector so that there is profound market efficiency. However, among our surveyed financial institutions, a lot of sensitive information such as possible change of ownership are still being undisclosed from the public shareholders. This not only creates market inefficiency but also results in poor investor confidence. As a result, this bites back at the corporation in the terms of reduced investors. Therefore, companies need to comply with corporate governance code of conduct and embrace the idea of information disclosure; otherwise they will be forever in the dark with a limited amount of investors as shareholders may feel reluctant to invest with the belief that they are treated unevenly.

\section{Effectiveness of the Board}

The presence of independent directors in the board helps by a mile to create unbiased and fairness in the decision making of the corporation. However, from our analyzed financial institutions we can see that only one company has taken the concept of appointing independent directors legitimately, whereas others have hired only around two. But despite those independent directors are taking active participation in the decision making process of the company. It is also a good sign of corporate governance when we found that all three CEOs are being evaluated not only routinely but by external auditors as well. As for board meetings and general attendance percentage, both are high and satisfactory.

Apart from the results presented from our primary data, we would also like to include some findings from secondary data extracted from Policy Brief on Corporate Governance of Banks in Asia (June 2006) developed by Asian Roundtable on Corporate Governance (ARCG) Task force. In this policy paper, some strong issues were discussed regarding corporate governance reforms in banks in Asia, saying that priority 
should be given to the following:

- The fiduciary responsibilities and duties of board members, their skills, and leadership traits

- The managerial functions of the board, such as strategic policy making and evaluation of corporate tactics

- The composition of the banks should be changed so that there are more independent directors, and chairman and CEO should not be the same individual

- There should be an audit committee, risk management committee, governance committee in the board for the purpose of nomination, remuneration, succession planning, training, performance, evaluation, etc.

- A bank's parent company should be careful in implementing the full extent of corporate governance within the group

- International methods and regulations of disclosure of information should be adopted

- Banks should continuously monitor and evaluate and also improve its corporate governance structure

\section{Conclusion}

In conclusion, we can witness that the philosophy of corporate governance in Bangladesh is still at the beginning stage. But the future of corporate governance is very optimistic especially in the financial institutions sector if we can overcome and outlast the problems by improving code of corporate conduct and other governance policies, by ensuring fiduciary disclosure of information, and a strong monitoring authority. The suggestions discussed in our study should also be taken into consideration but careful implementation of corporate governance mechanisms should be followed, otherwise there is the risk of backfire. For the application of strong corporate governance tools and instruments, it is not only the responsibility of the corporate body but up to the government as well. Robust, spirited, good governance helps not only the corporation and its shareholders but the society and the nation as a whole as well.

\section{Appendix}

A survey was conducted on Sound Corporate Governance And Its Benefits In Financial Institutions: Does It Really Matter for Organizational Development?

I. General Information of the company

Please put a tick beside the best option.

1. What is the ownership and control structure of the company?

- Ownership is fairly disseminated with no controlling shareholder

- Two or more shareholders collectively control the company

- Others, please specify

2. Is the company wholly or partially owned and control by the government?

- Yes, substantially owned and controlled by the government

- Partially owned, but not much controlled by the government

- Not owned or controlled by the government at all

3. What relation does the CEO have with the founder or the largest shareholder?

- Founder himself/herself

- Founder's family member

- Professional manager

4. What is the ownership/control structure of the biggest creditor bank of your company?

- Mainly government-owned

- Belong to the same business group as the firm

- Belong to a business group not related with the firm

5. How easy is it for your shareholders to participate in voting at the shareholders' meeting?

- Voting by mail allowed

- Proxy allowed

- Presence Required

II. Disclosure and Transparency

Does your company disclose the following information? If yes, then by what means?

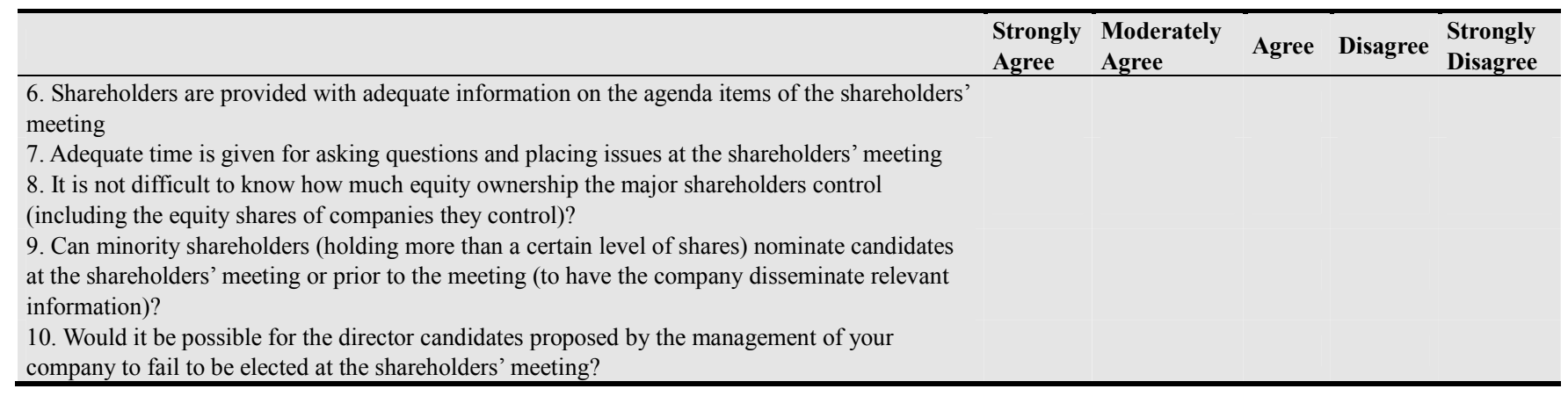

To what extend do you agree with the following statements? (Strongly agree $=5$, Moderately Agree $=4$, Agree $=3$, Disagree $=$

2, strongly Disagree $=1$ )

III. Shareholder Rights and Disclosure of Information

Web: company's web page

AR: Annual report

RR: Report to regulatory agencies

No: No disclosure 


\begin{tabular}{|c|c|c|c|c|}
\hline & Web & $\mathbf{A R}$ & $\mathbf{R R}$ & No \\
\hline \multicolumn{5}{|c|}{ 11. Directors' selling or buying shares in their company } \\
\hline \multicolumn{5}{|l|}{ 12. Resume/background of directors } \\
\hline \multicolumn{5}{|l|}{ 13. Remuneration of directors } \\
\hline \multicolumn{5}{|c|}{ 14. Fees paid to external auditors, advisors, and other related parties } \\
\hline \multicolumn{5}{|l|}{ 15. Policies on risk management } \\
\hline \multicolumn{5}{|l|}{ 16. Significant changes in ownership } \\
\hline \multicolumn{5}{|c|}{ 17. Governance structures and policies (explicit corporate governance rules and vision) } \\
\hline \multicolumn{5}{|l|}{ 18. Semi-annual reports } \\
\hline 19. Quarterly financial statements & & & & \\
\hline
\end{tabular}

\section{Effectiveness of the Board of Directors}

20. How many directors does your (supervisory) board have in total?

21. How many outside directors does your board have?

22. How many independent directors does your board have?

23. Does your board or compensation committee formally evaluate the CEO's performance?

- Yes, as a routine

- Sometimes

- Rarely

- Never

24. Is the CEO given a stock option?

- Yes

- No

25. How often do independent directors participating actively in board discussions?

- Often

- Sometimes

- Rarely

- Never

26. Does your company select/recommend the external auditor and conduct a proper review of his work?

- Very much so

- To some extent

- Hardly

27. Does the company provides any education or training opportunities for directors beyond what is mandatory?

- Actively

- Occasionally

- Never

28. How many board meetings were held last year?

- (2-3 times)

- (4-5 times )

- (6-7 times)

- (8 times or more)

29. What was the average attendance rate for board meetings?

- $(90-100 \%)$

- $(80-90 \%)$

- $(70-80 \%)$

- $(60-70 \%)$

- $(50-60 \%)$

\section{References}

[1] Cadbury, Adrian, Report of the Committee on the Financial Aspects of Corporate Governance, Gee, London, December, 1992, p. 15.

[2] Shailer, Greg. An Introduction to Corporate Governance in Australia, Pearson Education Australia, Sydney, 2004.

[3] OECD Principles of Corporate Governance, 2004. OECD. Retrieved 01-04-2015.

[4] Tricker, Adrian, Essentials for Board Directors: An A-Z Guide, Bloomberg Press, New York, 2009.

[5] Basel Committee on Banking Supervision, September 1997, Core Principles for Effective Banking Supervision, section II. Bank for International Settlement, Basel, Switzerland.

[6] Gillibrand, M. 2004. Corporate management essential for industrialization. The Bangladesh Observer, April 17, 2004.

[7] Ahmed, Mamtaz Uddin, and, Yusuf, Muhammad Abu. 2005. Corporate Governance: Bangladesh Perspective.

[8] Shahab Enam Khan (2006-2007). Economic Policy Paper on Institutionalization of Corporate Governance in Bangladesh.

[9] Huq, BIA \& Bhuiyan, MZH. Corporate Governance-Its Problems \& Prospects in Banking Industry in Bangladesh. (2012). World Review of Business Research (Vol. 2. No. 2. March 2012. Pp. 16-31).

[10] Committee on the Financial Aspects of Corporate Governance (CFACG; Cadbury Committee). (1992). Report of the Committee on the Financial Aspects of Corporate Governance. London: Gee and Co. Ltd Public accounts and Estimates Committee. Fifty second report to Parliament report on the 2002-03 budget estimates.

[11] The Promise of the Governed Corporation. (1995 April). Pound, J. Harvard Business Review.

[12] Furfine, $\mathrm{CH}$ 2001, "Banks as Monitors of Other Banks evidence from the overnight federal funds market", Journal of Business, Vol. 74, No. 1, pp. 33-57.

[13] Jensen, M\&C Meckling, WH 1976, "Theory of the Firm Managerial Behavior, Agency Costs and Ownership Structure", Journal of Financial Economics, Vol. 3, No. 4, pp. 305-360. 
[14] Rashid, A et al 2007, "Corporate governance in Bangladesh: an overview", in: 19th Asian-Pacific Conference on International Accounting Issues, 11-13 Nov 2007, Kuala Lumpur, Malaysia.

[15] Kutubi, SS 2011, "Board of Director"s Size, Independence and Performance: An Analysis of Private Commercial Banks in Bangladesh", World Journal of Social Sciences, Vol. 1, No. 4, pp.159-178.

[16] Davis, J.H., Schoorman, F.D. \& Donaldson, L. (1997). Toward a stewardship theory of management. Academy of Management Review, 22: 20-47.

[17] Kathleen Eizenhardt 1989 ("Agency theory: an assessment and review", Academy of Management Review).

[18] Sayeed, Y. (2002) "Bangladesh: Strageic Issues and Potential Response Initiatives in the Finance Sector: Bankging Reforms and Development", Paper Presented at Seminar Organized by Asian Development Bank and AIMS of Bangladesh, Dhaka, July 22 .

[19] Raquib, A. (1999) "Financial Sector Reform in Bangladesh: An Evaluation", Bank Porikorma, Vol. XXIV, No. 3 and 4.

[20] Hassen, M. (2008) "Why study corporate governance?"

[21] Corporate governance in financial institutions and remuneration policies by European Commission.

[22] OECD (2011) OECD Principles of Corporate Governance.

[23] Peter Mülbert, (2010). "Corporate Governance of Banks after the Financial Crisis - Theory, Evidence, Reforms ECGI - Law Working Paper No. 130/2009.

[24] Basel Committee on Banking Supervision, (Basel: BIS, February 2006) -Enhancing corporate governance for banking organizations.

[25] Hamid M, Alan M, Joel (2011) Corporate Governance and Banks: What Have We Learned from the FinancialCrisis? Federal Reserve Bank of New York Staff Reports ,Staff Report no. 502

[26] Kern Alexander, CORPORATE GOVERNANCE AND BANKING REGULATION, working paper 17.

[27] Jakob De Haan and Razvan Vlahu (2012) "Corporate governance of financial institutions: A survey".

[28] Dar es Salaam August, 2010 "RISK MANAGEMENT GUIDELINES FOR BANKS AND FINANCIAL INSTITUTIONS".

[29] A new paradigm "Financial institutions boards and supervisors" Published by Group of Thirty (C) Washington, D. C. October 2013.

[30] Minton, Bernadette A., Jérôme P. A. Taillard and Rohan Williamson, 2010. Board composition, risk taking and value: Evidence from financial firms.

[31] Faleye, Olubunmi and Karthik Krishnan, 2010. Risky lending: Does bank corporate governance matter?

[32] Cornett, Marcia Millon, Jamie John McNutt and Hassan Tehranian, 2010. The financial crisis, internal corporate governance, and the performance of publicly-traded U.S. bank holding companies.

[33] Pande, Santosh, The Theoretical Framework for Corporate Governance (October 26, 2011).
[34] Definition of corporate governance. Applied corporate governance. Retrieved 06-04-2015.

[35] Corporate governance in commonwealth authorities and companies, 1999. Australian audit office. Retrieved 05-042015.

[36] Berle \& Means, The modern corporation and private property, Macmillan, 1932.

[37] Dr. A.k. Enamul Haque, Farha Naz (2007), State of corporate governance in Bangladesh.

[38] Sreeti Raut (2014), Corporate governance- concept and issues

[39] The importance of corporate governance, CIPE development institute. Retrieved 07-04-2015.

[40] Dipok kumar roy. Corporate governance in financial sector. The Financial Express, Feb 11, 2015.

[41] Hamid Mehran, Lindsay Mollineux (Feb, 2012). Federal Reserve Bank of New York stuff reports on Corporate governance of Financial Institutions.

[42] Julie Davoren, Demand Media (2015). Three Types of corporate governance mechanism.

[43] RenÉeB.Adams, BenjaminE. Hermalin and MichaelS. Weisba, The role of board of directors in corporate governance: A conceptual framework and survey, Journal of economic literature, March, 2007. Vol. XLVIII, page 60-61.

[44] Hossain, AM (2008). Corporate Governance in Bangladesh: A Stock Market and Entrepreneurial Perspective. University of Saudi Arabia.

[45] Drew, S., Kelley, P. and Kendrick, T. (2006). CLASS: Five elements of corporate governance to manage strategic risk. Business Horizons, 49:127-138.

[46] Baucus, M. S., \& Near, J. P. (1991). Can illegal corporate behaviorbe predicted? An event history analysis. Academy of Management Journal, 34(1), 9-36.

[47] Schein, E. H. (1996). Organizational culture and leadership. San Francisco: Jossey-Bass.

[48] Hamilton, R. D., \& Kashlak, R. J. (1999). National influences on Multinational Corporation control system selection. Management International Review, 39(2), 167-190.

[49] Sankar, Y. (2003). Character not charisma is the critical measure of leadership excellence. Journal of Leadership and Organizational Studies, 9(4), 45-55.

[50] Labovitz, G. (2005, S). Well aligned: Using alignment to achieve extraordinary results. Builders and leaders, Boston University School of Management (pp. 24-25).

[51] Farrell, J. (2004). Internal controls and managing enterprisewide risks. The CPA Journal, 74(8), 11-12.

[52] Simons, R. (1995). Control in an age of empowerment. Harvard Business Review, 73(2), 80-88.

[53] Collins, D. (1997). The ethical superiority and inevitability of participatory management as an organizational system. Organization Science, 8(5), 489-507.

[54] Witherell, B (2002) Corporate governance and responsibility Foundations of market integrity. Observer. 
[55] Sang-Woo Nam, IL Chory Nam (2004): Corporate Governance in Asia, Annual Development Bank Institute.

[56] Becht, Marco, Patrick Bolton, and Alisa Röell. 2002. "Corporate Governance and Control." Working Paper no. 9371. National Bureau of Economic Research, Cambridge, MA.
[57] Bhagat, S., and B. Black, 1999. "The Uncertain Relationship between Board Composition and Firm Performance." Business Lawyer 54. 921-963. 